\title{
Contesting Constitutional Multi-Culturalism in Tanzania: The Trials of Christopher Mtikila
}

\author{
Michael Frank Lofchie \\ Department of Political Science, University of California, Los Angeles, USA
}

\section{Email address:}

mlofchie@polisci.ucla.edu

\section{To cite this article:}

Michael Frank Lofchie. Contesting Constitutional Multi-Culturalism in Tanzania: The Trials of Christopher Mtikila. Journal of Political Science and International Relations. Vol. 3, No. 2, 2020, pp. 26-35. doi: 10.11648/j.jpsir.20200302.11

Received: March 24, 2020; Accepted: April 27, 2020; Published: May 28, 2020

\begin{abstract}
Conflicts over the permissible limits on speech that weaponizes racial, religious, and ethnic identities are a global phenomenon. Tanzania's constitutional and legal debates over this matter are a microcosm of a global dialogue. Since the early years of independence, Tanzania has imposed constitutional and legal restrictions on speech that speech that espouses ethnic, religious, or racial divisions. These restrictions are the surviving portion of founder-President Julius Nyerere's multi-faceted effort to construct a multi-cultural political environment. Tanzania's early leaders were deeply aware that ethnic rivalries had come to cominate the political life of other countries in their region. They were determined that Tanzania should become and remain the non-Sudan, non-Rwanda, and non-Kenya of Eastern Arica. They did so by introducing constitutional and restrictions on ethnic political appears into the country's constitution and electoral laws. Since independence, each iteration of the Tanzanian Constitution has forbidden the registration of political parties that base their electoral appeal on these forms of speech. Tanzania has also embedded these limitations in its electoral laws, which limit candidacy for electoral office, at both national and local levels, to candidates nominated by registered parties. These limitations have given rise to more than twenty years of constitutional litigation. This article presents a study of the key constitutional cases. The methodology of this article is a close examination of a series of trials in which Tanzania's constitution and electoral laws have been subjected to litigation. Four trials are of utmost significance: two, before the Tanzanian High Court; one, before the Tanzania Court of Appeal, and one before the African Court of Human and People's Rights. Despite adverse court rulings, Tanzania's political leaders appear determined to retain the restrictive portions of their constitution and electoral system; these remain in place to the present time.
\end{abstract}

Keywords: Human Rights, Ethnic Politics, Tanzania, Political Trials, Multiculturalism, Freedom of Speech

\section{Introduction}

Conflicts over the boundaries of speech that weaponizes racial, religious, and ethnic identities are a global phenomenon. Free speech advocates emphasize the value of an open marketplace for expression, insisting that beneficial ideas can displace harmful ones in a Darwinian competition for public acceptance. Others advocate limits on forms of speech that exacerbate those social divisions, sometimes termed "hate speech." They argue that these forms of speech can inflict traumatic hurt on targeted individuals or groups and incite political violence. The debate between these viewpoints has absorbed the attention of countless scholars, jurists, legislators, academic administrators, and political philosophers [1]. The literature on this topic is of such encyclopedic proportions that no single monograph can convey the variation across countries. This paper considers the legal trajectory of this issue in Tanzania.

The most fruitful point of departure is an understanding that countries everywhere impose limits on speech. The United States, sometimes regarded as one of the more libertarian nations owing to the protections for speech afforded by the first amendment to the constitution, imposes significant limitations. First amendment protections do not extend to individuals who have committed libel, slander, or perjury or those who may have exposed governmental secrets. Courts have also accorded limited discretion over public lectures to university administrators, whose responsibility to create an atmosphere conducive to student learning, "can impose certain restrictions on outside speakers based on the recognition that their focus and function is distinct from many other civic forums [2]." Even Denmark, a country long 
regarded as a bastion of free speech, the country that defended mawkish cartoons of the Prophet Mohamed, has begun to restrict speech that inflames religious animosity. The European Court on Human Rights, which derives its legal principles from the European Convention on Human Rights, has begun to view hate speech ... as an 'abuse' of [the Convention] and therefore allows it no legal free speech protections [3]." The common denominator of these restrictions is a conviction that the harmful effects of speech that inflames racial, religious, and ethnic animosities can outweigh the benefits.

\section{Purpose and Method}

Tanzania is among the many countries that have imposed significant limitations on the content of speech, thereby offering a microcosm of a global phenomenon. It may differ from others only in having embedded these limitations in its successive constitutions and in its electoral law, and in having consistently defended these provisions in its courts. The purpose of this article is to call attention to the legally contested nature of the its constitutional and legal prohibitions and to demonstrate the Tanzanian Government's resolute determination, over more than twenty years of litigation, to preserve these. The methodology we pursue is a case study examination of the principal constitutional trials where these issues have been litigated.

For the Tanzanian Government and for many individual Tanzanians, the most important constitutional prohibition is a long-standing ban against unaffiliated candidates; that is, candidates who are not nominated by a registered political party. Tanzania's first generation of national leaders believed that permission for unaffiliated candidates would open the political door to locally popular ethnic notables who might easily defeat the candidates of a national political organization seeking to build a multi-cultural political environment. For the Tanzanians who oppose this restriction, it represents an impermissible barrier to the fundamental human rights of freedom of association and speech. Tanzania's constitutional and legal prohibitions against individual candidacies have been tested repeatedly in its national courts and in an international court, the African Court on Human and Peoples' Rights [4].

Practically all of the constitutional litigation on this matter has been initiated by a single political figure. In a lengthy series of trials that spanned the period from 1993 to 2013, Reverend Christopher Mtikila, leader of an opposition party called the Democratic Party (DP), sought court judgments on the constitutionality of the ban on unaffiliated candidates. Mtikila filed four lawsuits that dealt with this issue; two, before the Tanzanian High Court; one before the Tanzanian Court of Appeal, and one with the African Court on Human and People's Rights. Mtikila's cases did not ask the Tanzanian courts to exercise the sort of judicial review that is familiar in the United States; that is, the authority of the court to strike down ordinary legislation it considers inconsistent with constitutional provisions. His cases asked the courts to strike down the constitutional provisions that prevented individual candidacies on the basis that these violated the basic human rights of association and speech and were, therefore, inconsistent with those rights as well as other constitutional provisions that appeared to guarantee those rights.

The Mtikila lawsuits posed a daunting constitutional question: what happens when one set of provisions in a constitution is inconsistent with other provisions? In briefest terms, Mtikila asserted that the constitutional requirements for elective candidacy meant that Tanzania had an unconstitutional constitution. For a political party to become registered, it must satisfy the registrar that it does not appeal based on ethnic or religious concerns. Since candidacy for the presidency, National Assembly, or local councils is restricted to the nominees of registered parties, individuals not affiliated to parties, and whose political convictions invoke ethnic or religious issues cannot be eligible. However, Articles 20 and 21 of the constitution contain language that affirms Tanzania's commitment to basic human rights including the right to participate freely in the country's political process. Since the right to participate freely includes the right not to join a political party, the courts must strike down the party affiliation (and nomination) requirement.

Mtikila's purpose was clear. By eliminating the constitutional and legal ban on unaffiliated candidates, he hoped to open the political arena to forms of speech that were otherwise constitutionally and legally impermissible. Mtikila's legal reasoning, which remained constant in all of his constitutional cases, was straightforward. Since the authors of the 1977 Constitution and its various amendments did not anticipate unaffiliated candidates, the constitution and electoral law have always been silent on whether the prohibitions that apply to nominated candidates also apply to them. Absent an explicit constitutional or legal proscription against racial, ethnic, or religious speech, unaffiliated candidates would presumably be free to engage in those forms of public expression. If Mtikila's lawsuits succeeded, there could be two categories of candidates; party-nominated candidates, who would be subject to constitutional and legal restrictions on speech, alongside individual candidates, who would not.

Court procedures in Tanzania as elsewhere require a plaintiff to seek a remedy. Mtikila's remedy was for Tanzanian courts to strike down the constitutional provisions that proscribed unaffiliated candidacy and, presumably, the forms of speech such candidates might employ. Legal scholars refer to this as a matter of "harmonizing" the constitution and they have grappled with whether courts have authority to carry out a harmonizing exercise as well as with the substantive merits of the constitutional issue. A leading proponent of the view that assigns courts the authority to harmonize a constitution, Yaniv Roznai, uses the term "foundational structuralism" to refer to this principle. He bases his argument on a distinction between the people as the holders of the constitution-making power and the organs of government to which they entrust the power to change a 
constitution [5]. The common term for this idea is basic features theory. Roznai theorizes that, in entrusting a government the authority to modify or amend the language of a constitution, the people are not surrendering to government the authority to take away their basic human rights. Briefly, basic features theory asserts that basic human rights such as speech, association, and public participation arise and exist outside a constitution and that constitutional documents merely give a written form to those rights. Under basic features doctrine, a government's authority to create or amend a constitution stops short of amending human rights out of the constitution.

Mtikila's lawsuits depended on the basic features idea. In all of his constitutional cases, Mtikila's attorneys invoked this doctrine to attack the constitutional provisions that required nomination by a registered party to stand for office. The normative core of Mtikila's legal position was that, under the basic features doctrine, the authors of Tanzania's constitution did not have the authority to create or amend a constitution that abridged basic human rights.

\section{The Tanzanian Background}

Today, little remains of the three-part legacy founderpresident Julius Nyerere had hoped to bequeath to his country. His most cherished goal, the creation of a socialist economy, ended in the mid-1980s, when Tanzania transitioned to a market-based system. The single-party political system he believed could democratically represent the interests of all Tanzanians ended with the return to a multi-party system in the early 1990s. A third portion of Nyerere's legacy, however, remains largely intact, a constitutional framework and electoral system whose purpose is to deter the use of race, ethnicity, or religion as bases for contesting elective office. When Tanzania become independent in December 1961, the first-generation nationalist leaders were well aware of the extent to which ethnic loyalties threatened to define the political life of other countries in the region. Ethnic, racial and religious cleavages already dominated the political life of other countries in eastern Africa such as Sudan, Kenya, Uganda, and Rwanda. Tanzania's early leaders were determined that their country should become - and remain the non-Kenya, non-Rwanda, and non-Sudan of eastern Africa. The lesson of those countries was unmistakable. The founder-nationalists of Tanzania believed that a culture of ethnic peace would not arise spontaneously and it would not remain in place by itself. It would require a purposeful and systematic effort that included both positive inducements and a set of constitutional and legal deterrents against the introduction of ethnicity, race, or religion into the country's political discourse.

\subsection{Multi-Cultural Policies}

To create a multi-cultural political environment, Tanzania's first generation leaders adopted a variety of policies. In National Assembly elections, the governing party, Tanganyika African National Union (TANU) sometimes made a conspicuous point of nominating candidates whose ethnicity differed from the constituency in which they stood. By making Swahili the language of instruction in public schools and the official language of the government, the government hoped to create a language bond that would cut across ethnic and religious boundaries. Education policy was critical; the TANU Government abolished the colonial inheritance of separate racial and religious schools; all schools became public schools and the government sought to make certain that each school had a mix of students. So long as budgetary resources were available, all of Tanzania's secondary schools were boarding schools. The government took great pains to see to it that the students and teachers in each of these schools came from different regions, thereby assuring that each school would have a mix of different ethnic and religious communities. In each of these schools, students of diverse backgrounds attended the same classrooms, played on the same sports teams, and participated together in their school's dramatic clubs and musical societies. The government also created a National Service program. In the NSP encampments, young Tanzanians from all regions of the country came together and built cross-cultural friendships by sharing nation-building experiences.

\subsection{Consitutional and Legal Provisions}

Tanzania's founding leaders also introduced a set of constitutional and legal deterrents whose purpose was to erect political barriers against organizations or leaders that might seek to take advantage of the political volatility of racial and ethnic identity. The first constitution to reflect this objective fully was the 1965 Constitution, which created the single-party state and made party membership and nomination a qualification for elected office. Section 27 (1) of this constitution also banned unaffiliated candidates [6]. This provision accomplished two related purposes. It eliminated a growing political threat from the African National Congress (Tanzania), a populist opposition that was building a popular following by vocalizing strident antiAsian sentiments. It also eliminated the threat TANU candidates might face if they had to campaign against locally popular figures, campaigning on local ethnic solidarity.

The prohibition against individual candidacies was so fundamental that each successive Tanzanian government has retained it. Despite all the other changes that have taken place in contemporary Tanzania, which include the return to a multi-party system and acknowledgement that a market economy generates a wide multiplicity of social interests, the prohibition against unaffiliated candidacies that first appeared in the 1965 constitution remains in place. This requirement is also embedded in the country's electoral law. Article 36 of the National Elections Act of 2010 stipulates that candidacies for Parliament must comply with Article 67 (b) of the (1977) Tanzanian Constitution, which requires nomination by a registered party as a condition of standing for elective office The prohibition against individual candidacies operates in tandem with constitutional provisions 
that prevent the registration of any party that "aims at promoting or furthering the interests of any faith or religious group [or] any tribal group [7]." Taken together, this set of provisions imposes strict boundaries on the speech candidates may employ to gain popular support. To this day, no candidate may run for office unless he or she has the nomination of a registered party and no party may register whose candidates espouse racial, religious, or ethnic forms of speech.

\subsection{Reverend Christopher Mtikila}

Mtikila was an outspoken opposition figure. Born in 1950, he grew up during the formative era of Tanzanian nationalism but was an opponent of TANU from an early age. In a biographical interview, he recalled that, even as a high school student, he had refused the headmaster's insistence that he join the TANU Youth League because he opposed Nyerere's socialist ideas [8]. In 1982, at age 32, Mtikila had a religious awakening and became a pastor in a small Pentecostal denomination known as the Full Salvation Church. While pastoring his church, he also became active in its human rights organization, the Liberty Desk. In the early 1990s, just as Tanzania was beginning its transition to a multi-party system, he formed the DP.

Mtikila's views about national identity were diametrically opposed to the viewpoint Nyerere had embedded in the country's constitution and electoral laws. Nyerere believed that a sense of Tanzanian nationhood would have to be carefully and deliberately constructed out of an ethnically, religiously, and racially plural society. He was well aware that appeals to race, religion, or ethnicity could attract levels of popular support that would overwhelm candidates espousing a multi-cultural view. Because a constructed sense of national identity would be inherently vulnerable, it would require constant nurturing and reinforcement. The scaffolding necessary to do so would consist of positive inducements, such as the multi-ethnic schools, and deterrents, such as the constitutional provisions and electoral laws that prevented politicians from exploiting latent ethnic strains. Mtikila held a nativist vision that saw the nation in immutable, ancestral terms. For Mtikila, the true Tanzanian nation consisted of Africans of indigenous descent, not the offspring of immigrant minorities who came later such as Asians or Arabs, whose presence had created a racial caste system.

\subsection{Anti-Asian Sentiment}

Mtikila's principal target was Tanzania's Asian community, which, though only a small portion of the population, constituted a visible, prominent, and racially differentiated middle class. Some Asians were among the wealthiest Tanzanians. As a community, Asians were preeminent in Tanzania's professional strata, as the owners or managers of Tanzania's largest banking and trading firms, and as the upper tier white-collar employees in the Tanzanian Government. Historian James Brennan has shown that antiAsian sentiments were a pervasive and powerful political force during the 1960s. These were frequently articulated in the popular media, which portrayed resident foreigners, especially Asians, as parasitic exploiters [9]. Asian privilege provided aspiring political leaders with a ready basis of political traction. Even TANU leaders sometimes sought popular support by decrying the social separateness of the Asian community. Their criticisms focused on the tendency of Asians to lead lives of privilege in segregated neighborhoods, their habit of using Indian languages as the language of the household and lack of fluency in Swahili. The social behavior of some Asian busines owners, who mistreated African employees, gave the Asian community as a whole a reputation for holding racially disparaging views about Africans.

Mtikila's anti-Asian sentiments took advantage of this politically volatile current of Tanzanian public opinion. Throughout his political career, he had a reputation as a populist demagogue given to extreme speech that injected divisive racial issues into Tanzanian politics. Many of his speeches sought to arouse political support based on latent racial tensions between economically poor Tanzanian workers and Asian employers or shopkeepers. The sociologist Ronald Aminzade has portrayed Mtikila as an advocate for social groups that felt left behind by economic change and forgotten by their government, an imagery painfully familiar in so many countries [10]. He portrayed Mtikila as an anti-immigrant populist with strong appeal to urban, working class Africans.

Many admired Mtikila's courage in speaking out publicly and forcefully about the taboo issue of racial inequality, particularly at a time when the government's neoliberal economic policies were widening the economic divide between the races. In Mtikila's view, the nation's enemies were Asians, a dominant racial group that had refused assimilation into African culture, non-Christian Zanzibaris, whose international Muslim ties made their loyalty to the nation questionable, and rich Asian and Arab businesspeople, a wealthy group who had exploited the oppressed indigenous black majority for centuries.

Mtikila's views resonated with Africans who eked out a precarious living as informal sector street vendors, and whose presence along major thoroughfares provoked opposition from large storeowners, many of whom were of Asian descent. There was no doubt about Mtikila's personal popularity with Africans struggling with the country's difficult economic conditions; Aminzade cites opinion surveys showing that, by 1995, Mtikila had become one of the most popular politicians in the country.

Few Tanzanians doubted the racially inflammatory content of Mtikila's rhetoric. In his speeches, he typically alleged that even after several generations in Tanzania, Asian families still used Indian languages instead of Swahili as the language of the household; that their rates of inter-marriage with Africans were low, and that they rarely socialized with Africans outside the workplace. He sometimes referred to Asians as "magabacholi," a Swahili word meaning parasites that was a pejorative term for Asian business people. His 
speeches drew contrasts between the "magabacholi" and the "wazawa," - native-born Africans - and with "walala hoi," a term describing African workers who fall asleep at night from utter exhaustion. When the DP called for the expulsion of non-indigenous minorities from the mainland portion of Tanzania, most Tanzanians understood this phraseology as political code language for Asians [11].

Mtikila's speeches also included strong attacks on the union between Tanganyika and Zanzibar, depicting that union as highly disadvantageous to Africans in mainland Tanzania. His repeated insistence that Zanzibar dominates the union both politically and economically played on the historical role of Zanzibar as the geographical center of the East African slave trade. Because many Tanzanians perceive Zanzibar as an Islamic region of the country, the notion of Islam as the historic religion of those who enslaved Africans was also readily discernible in Mtikila's appeal for popular support.

There was a vast discrepancy between Mtikila's apparent personal popularity, as evidenced by the large gatherings that attended his political rallies, and his limited electoral success. Because the DP did not comply with the country's difficult registration requirements until 2002, Mtikila did not run for president until 2005, the country's third multi-party election. He received only about 31,000 votes, approximately .27 percent of the nearly eleven million votes cast. By comparison, Jakaya Kikwete, the CCM presidential candidate received over 9,100,000 votes. One Tanzanian informant, called upon to explain Mtikila's electoral weakness, referred to Mtikila's vocal anti-Asian sentiments by saying, "This is not Tanzanian." The discrepancy between Mtikila's personal popularity and his inability to translate this popularity into electoral success provides us perhaps the most tangible evidence of the enduring influence of Nyerere's multicultural ethos. Despite his inability to attract broad electoral support for his views, Mtikila insisted that constitutional guarantees of free association and speech required the Tanzanian Government to allow him - and others - to campaign openly based on those viewpoints.

\section{The Constitutional Trials}

Even the most casual reader of the Tanzanian Constitution would find it a jumble of contradictory provisions. Passages that appear to offer broad guarantees of individual and organizational expression appear side-by-side with provisions that impose restrictions on the forms of speech that the candidates of registered parties may employ. Articles 20 and 21 of the 1977 Tanzanian Constitution grant Tanzanian citizens sweeping rights to participate freely in their country's political process. Articles 39 and 67 of the Constitution, however, require nomination by a registered party to stand for office, and disqualify parties that espouse a racial, religious or ethnic platform.

The most glaring example of the tension between freedom and deterrence in the Constitution appears within a single section, Article 20. Section 1 grants a set of fundamental freedoms.

Every person is entitled to freedom, subject to the laws of the land, to freely and peaceably assemble, associate and cooperate with other persons, express views publicly and more specially to form or join associations or organizations formed for the purposes of preserving or furthering his beliefs or interests or any other interests.

Section 2 of this article, however, limits those freedoms by refusing the right to register for political parties with an ethnic appeal or local base of support.

Notwithstanding the provisions of sub-article (1) it shall not be lawful for any political entity to be registered which according to its constitution or policy - (a) aims at promoting or furthering the interests of: (i) any religious faith or group; (ii) any tribal group, place of origin, race or gender, (iii) only a particular area within any part of the United Republic;

Adding inconsistency-to-inconsistency in a bewildering sequence, section 4 states that the government cannot refuse to register a party based on its political philosophy.

"It shall be unlawful for any person to be compelled to join any association or organization, or for any association or any political party to be refused registration on grounds solely [of] the ideology or philosophy of that political party."

Article 21 of the Constitution exhibits the same inconsistencies. It begins by granting citizens of Tanzania a sweeping right to participate freely in their country's political affairs - "every citizen of the United Republic is entitled to take part in matters pertaining to the governance of the country, either directly or through representatives freely elected by the people." It then narrows this right by specifying the need for conformity with Articles 39 and 67, which require nomination by registered political parties.

Tanzania's constitutional restrictions on speech reappear in the ordinary laws governing the registration of parties and eligibility of candidates. Section 8 (2) of The Political Parties Act, which first passed in 1992, repeats verbatim the constitutional language proscribing parties that appeal to ethnicity or race.

"Without prejudice to subsection (1) of this section no political party shall quality for provisional registration if by its constitution or policy--- a) aims to advocate or further the interests of - (i) any religious belief or group; (ii) any tribal, ethnic or racial group; or (iii) only a specific area within any part of the United Republic... [12]."

Historic concerns about the political volatility of racial appeals may have haunted the authors of this law. In an obvious attempt to prevent the return of the ANC (Tanganyika) to the electoral arena, this law contains an otherwise inexplicable provision banning the revival of any party, or the acronym of any party, that existed before the union between Tanganyika and Zanzibar, which took place nearly thirty years earlier, in April 1964.

What is the reasonable person to make of all this? The most likely answer is that Tanzanians, like the citizens of so many nations, are of two minds about free speech. They value it as a matter of principle and for the personal freedoms that arise in an open society. They also share the concern of 
their country's founding leaders; namely, opening the constitutional door to ethnic, racial, or religious speech could do irreparable damage to the country's multi-cultural political fabric. Tanzania would experience a political pattern similar to African countries where ethnic identity often forms a salient and often volatile basis of political affiliation.

\subsection{The First Trial: 1993}

Mtikila's first major constitutional case, Civil Case No. 5 of 1993, came before the Tanzanian High Court that year. The immediate precipitant of this case was the National Assembly's passage of a law called the Eighth Constitutional Amendment Act of 1992 (Act No. 4 of 1992). This amendment changed the constitution to allow a multi-party system but left unchanged the requirement that individuals seeking office to have the nomination of registered political parties [13].

The High Court's judgment, delivered on October 24, 1994, utilized the basic features doctrine to state the inalienability of basic rights and strike down the constitutional restriction on individual candidates to which Mtikila objected.

"Fundamental rights are not gifts from the state. They inhere in a person by reason of his birth and are therefore prior to the State and the law ... Modern constitutions like our own have enacted fundamental rights in their provisions. This does not mean that the rights are thereby created; rather it is evidence of their recognition and the intention that they should be enforceable in a court of law [14]."

In the court's judgment, the constitutional provisions that restricted Tanzanians' rights of organization, expression and electoral contestation "are restrictions on the exercise of a fundamental right and not fundamental in themselves. It is the fundamental rights, but not their restrictions, that this court is enjoined to guard jealously." The High Court concluded its judgment by affirming the right of unaffiliated candidates to stand for elective office. The judge declared, "I declare and direct that it shall be lawful for independent candidates, along with candidates sponsored by political parties, to contest presidential, parliamentary and local council elections."

The High Court did not strike down the onerous registration requirements for political parties nor the constitutional and legal ban against ethnic forms of speech on the part of party nominees. The court reasoned that, so long as unaffiliated individuals could participate freely outside the party system, the requirement to register a political party is not a fundamental barrier to the right of participation, speech, or association. So long as individuals could participate freely without party affiliation, participation through a political party should be viewed as a procedural choice. Only if the right of participation were restricted to political parties, would it then become a substantive matter. The High Court's judgment appeared to give Mtikila exactly what he was seeking. If the government had carried out the judgment, Tanzania would have two categories of candidates; those nominated by duly registered political parties and those standing as unaffiliated individuals. There would be a major difference between the two categories as regards permissible speech: the unaffiliated candidates, unrestricted by the constitutional and legal prohibitions on speech that applied to candidates of registered parties, would have wider freedom to utilize ethnic, religious, or racial speech.

The story of Mtikila's constitutional litigation could have ended at that point if the Tanzanian Government had accepted the Court's judgment and taken steps to implement it. More than twenty years later, however, it has yet to do so. Instead, the government has used a variety of tactics including bureaucratic delays, legal appeals, the adoption of new constitutional amendments, and the passage of contradictory legislation in the National Assembly, to avoid the High Court ruling. Anticipating a negative outcome even before the High Court issued its decision, the Tanzanian Government had already begun to lay the constitutional and legal groundwork to forestall an adverse ruling. In December 1994, just two months after the High Court ruling, the Assembly passed a new law that applied to constitutional cases and placed the High Court decision on legal hold. The government titled its new law the Basic Rights and Duties Enforcement Act (BRDE) of 1994 [15].

The title of this law is misleading. Its purpose was to reverse the High Court's decision in the 1994 Mtikila case. Instead of making it possible for Tanzanians to use the courts to enforce their rights, the BRDE makes it more difficult, indeed almost impossible, for them to do so. The BRDE first stipulates that cases involving human rights must come before a panel of three judges; a majority decision is required. This meant that, unlike the previous situation, where a single judge could decide about human rights, it now required at least two judges to do so. The most important impact of BRDE, however, was to remove the High Court's authority to declare unconstitutional the provisions of a constitution that compromise basic human rights such as speech, association, and participation. Under the BRDE, if the High Court should conclude that there is a constitutional issue, it must refer the matter to the National Assembly. Simultaneously, the National Assembly also passed Constitution (Eleventh) Amendment, Act No. 34 of 1994 [16]. This amendment restored the constitutional and legal position to its pre-Civil Case \# 5 status by making the right to contest for the offices of President, Vice President and National Assembly subject to Articles 39, 47 and 67, which require nomination by a registered political party.

\subsection{The Second Trial: 2005}

Whatever opinion Tanzanians may have held about Mtikila's political views and those of his Democratic Party, many came to admire his indefatigable determination to pursue through the court system the basic rights and freedoms that the executive and legislative branches of the Tanzanian Government appeared determined to deny. He began his next major constitutional action twelve years later in 2005, filing a lawsuit to force the Attorney General to implement the court's 1994 judgment. The High Court did not hear this case until mid-2006. The basic issue was 
identical to Civil Case No. 5 of 1993; namely, the government's on-going refusal to permit individual candidacies. The High Court pronounced its judgment about a year later, in early May, 2006. As specified in the BRDE, Mtikila's new case came before a panel of three judges. What is especially noteworthy about the 2005 trial, then, was the Court's unanimous judgment in Mtikila's favor. Although the High Court for this case convened under the three-judge format prescribed in the BRDE law, it issued a stern rebuke against the government for its dilatory tactics. In a clear reference to the 1994 BRDE law and the Constitution (Eleventh) Amendment Act of 1994, the court's judgment included the following language.

"While the ruling (in Civil Case No. 5) was being awaited, the Government presented a bill in parliament seeking to amend the constitution so as to deny the existence of that right, thus pre-empting the Court ruling should it go against the Government... The Government was now adopting parallel courses of action towards the same end by asking Parliament to deal with the matter simultaneously with the High Court... Thus, the government consciously and deliberately drew the judiciary into a direct clash with Parliament by asking the two organs to deal with the same matter simultaneously."

This judgment also upheld the decision it had made in Civil Case No. 5, twelve years earlier, upholding the right to participate in the political process without the requirement of nomination by a registered party.

"There is no evidence at all to suggest that the existence of the right of private candidate is inimical to the spirit of representative democracy...We are of the unshakable view that political party membership as a qualification to being nominated for an elective post is too unnecessary a restriction for the purposes of achieving and maintaining morality, public order and general welfare of the people [17]."

The High Court's judgment had a fatal weakness. Under the terms of the BRDE, the Tanzanian Courts did not have jurisdiction over constitutional issues; they are obligated to refer these to the National Assembly for legislative consideration.

\subsection{The Third Trial: The Tanzanian Court of Appeal (2009)}

The High Court's rebuke of the government's delays and its judgment in favor of unaffiliated candidacies proved futile. After doing nothing for three years, the Government of Tanzania appealed the Mtikila decisions to the Tanzania Court of Appeal in early 2009. The Court of Appeal rendered its judgment the following year. On June 17, 2010, a full seven-judge panel of the Tanzanian Court of Appeal overturned both High Court decisions. It ruled that the neither the High Court nor the Court of Appeal had the authority to harmonize the constitution -that is, to reconcile conflicting constitutional provisions - since this authority had not been explicitly assigned to the courts in the constitution.

"So, if there are two or more articles or portions of articles which cannot be harmonized, then it is Parliament which will deal with the matter and not the Court unless that power is expressly given by the Constitution, which, we have categorically said, it has not."

The Court of Appeal ruling held that, since constitutional inconsistencies were a political matter, the courts' obligation was to refer these to the National Assembly for reconciliation. On the fundamental matter of individual candidacies, the Court of Appeal also ruled that this was also a political matter and, therefore, the responsibility of the National Assembly.

"In our case [Civil Appeal No. 45.], we say that the issue of independent candidates has to be settled by parliament which has the jurisdiction to amend the Constitution and not the Courts which, as we have found, do not have that jurisdiction. The decision on whether or not to introduce independent candidates depends on the social needs of each State based on its historical reality. Thus the issue of independent candidates is political and not legal [18]."

The Court of Appeal decision voided the two High Court decisions that allowed unaffiliated candidates, assigning jurisdiction over this matter to Tanzania's National Assembly.

It is difficult to gauge the Tanzanian public's reaction to the Court of Appeal decision. Election results in Tanzania show scant evidence of a broad public outcry in favor of individual candidacies. In the 2015 parliamentary elections, the DP's parliamentary candidates secured less than 15,000 votes, about .1 percent of the nearly fifteen million Tanzanians who voted. The DP did not elect a single assembly candidate. None of the other parties made an issue of the Court of Appeal decision; perhaps because, having navigated the challenging registration process, they shared the CCM's disinclination to face individual candidates who might have a local ethnic basis of support. Although there were allegations of voter suppression, including harassment and arrest of opposition supporters, most observers agreed that the results of the 2015 election are broadly representative of the distribution of Tanzanians' party preferences [19]. CCM spokespersons point to the election outcome and the absence of a public outcry over the Appeals Court decision to claim that the majority of Tanzanians do not find the country's electoral (or speech) restrictions objectionable. They insist that, in the trade-off between the country's prized atmosphere of ethnic peace and freedom for individual candidates to make ethnic or racial appeals, Tanzanians prefer the former.

Members of the Tanzanian judicial community, on the other hand, have reacted with outrage at the Court of Appeal judgment. In an address given on 25 November 2010, retired Chief Justice Barnabas Samatta, one of Tanzania's most distinguished jurists, stated that the Court of Appeal decision gave the National Assembly unlimited power to modify the constitution in ways that might compromise democratic values.

"Could the framers of the fundamental instrument have intended to confer on the legislative organ almost unlimited amending powers? Was the power of amendment intended to include the power to destroy or emasculate basic democratic 
values and principles enshrined in the fundamental law? The Court of Appeal' answer to that question would be: YES [20]."

In his address, Samatta suggested that the logical effect of the Court of Appeal decision was to free the National Assembly to create a life presidency, if it so chose, or to create a power of executive discretion over the rights and freedoms to be enjoyed in the future by Tanzanian citizens. For Samatta, the most disappointing aspect of the Court of Appeal decision was its rejection of the basic features doctrine; namely, that constitutions do not create basic human rights; they simply give them verbal expression.

Samatta's essay observes that the Court of Appeal offered no response to the nearly twenty years of Tanzanian legal opinion to the effect that the issue of independent candidacies was constitutional and, indeed, that it was explicitly addressed in the human rights provisions of the Tanzanian Constitution such as Article 20. In its judgment, the Court of Appeal did not address the fact Tanzania was an adherent to several international treaties on human rights such as the Universal Declaration of Human Rights and the African Charter for Human and Peoples Rights. These appeared to have a direct bearing on the issue of individual candidacies. The Court had simply stated that inasmuch as Tanzania's adherence to those treaties had not been a determinative factor in the lower court's judgments, it did not merit significant weight in the decision to reverse those judgments.

Since the Court of Appeal is Tanzania's highest court, its judgment meant that Mtikila had exhausted his legal remedies within Tanzania. By rendering this decision, it had created a dystopian legal environment in which the Tanzanian courts had lost their ability to use the constitution as a basis for defending human rights. Mtikila had to look outside Tanzania for legal redress.

\subsection{The Fourth Trial: African Court on Human and Peoples' Rights (2011)}

In June 2011, about a year after the Court of Appeal decision, Mtikila filed a case with the African Court on Human and People's Rights. (Hereafter, African Court.) The African Court heard arguments in June 2012 and announced its judgments about a year after that, in mid-June 2013. The arguments Mtikila placed before the African Court relied heavily on the international agreements to which Tanzania was a signatory. For example, his application to the Court cited Article 13, Section 1 the African Charter on Human and Peoples' Rights on the right to free participation.

"Every citizen shall have the right to participate freely in the government of his country, either directly or through freely chosen representatives in accordance with the provisions of the law [21]."

Mtikila's application to the African Court also pointed out that Tanzania had ratified the International Covenant on Civil and Political Rights, Article 25 of which states, "every citizen shall have the right and opportunity ... without unreasonable restrictions, to take part in the conduct of public affairs directly or through freely chosen representatives [22]." The core of Mtikila's argument before the court was - as it had been for nearly twenty years - that Tanzania's constitutional and legal requirement that candidates for office must be the nominees of registered political parties constituted an impermissible form of discrimination against individuals who wished to participate in their country's affairs while not affiliated with any political party.

The legal scholar Oliver Windridge considers the Mtikila case watershed in African legal history. He states, "The case is the first to be decided on its merits at the African Court, the first to find in favor of the applicants, and the first to consider the issue of reparations and damages [23]." The Mtikila case was also the first in which an individual and NGO appellants had successfully navigated the African Court's daunting jurisdictional requirements. Before the African Court could even begin to review the Mtikila case on the merits, it had to consider a fundamental prior question. One of the preconditions for bringing a case forward to the African Court was a stipulation that the appellants must first have exhausted their local remedies. The Tanzanian Government asserted that they had not done so. In 2011, at about the same time that Mtikila was bringing his case forward to the African Court, it had begun to assemble a Constitutional Review Commission whose purpose was to solicit public opinion in Tanzania in the country in order to produce an amended constitution that could be considered by the National Assembly. The Government's attorneys argued that Mtikila and the NGOs had not exhausted their local remedies by seeking parliamentary action on the matter and participating in the Constitutional Review Commission process.

The African Court rejected the Tanzanian Government's argument. It cited relevant provisions of the African Charter, which stipulate that local remedies must meet the criteria of availability, effectiveness, and sufficiency. In the Court's judgment, neither parliamentary action nor the Constitutional Review Commission met these criteria.

"The parliamentary process... is not an available, effective and sufficient remedy because it is not freely accessible to each and every individual; it is discretionary and may be abandoned anytime... No matter how democratic the parliamentary process will be, it cannot be equated to an independent judicial process for the vindication of the rights under the Charter."

The wording of the African Court judgment on this matter raises an awkward question about the behavior of the Tanzanian Government. Was the Tanzanian Government using the Constitutional Review Commission as means to evade and postpone the human rights commitments it had embedded in its own constitution and to which it had further committed itself as a signatory to the African Charter? In Windrige's view, the African Court had announced its determination to pierce the veil of governmental procedures. It would refuse to allow Tanzania or other African governments to create constitutional review processes as a pretext for preventing constitutional cases from coming forward. On the merits of the case, the African Court found in favor of Mtikila. Its ruling required Tanzania to permit unaffiliated candidacies. 
"The Court therefore finds that by requiring individuals to below to and to be sponsored by a political party, in seeking election in the Presidential, Parliamentary and Local Government posts, the Respondent has violated the right of freedom of association [24]." In supporting this conclusion, the African Court cited a United Nations document that proscribes a requirement of party affiliation as a basis candidacy. It states, "The right of persons to stand for election should not be limited unreasonably by requiring candidates to be members of parties or of specific parties [25]."

The Court held Tanzania's constitution and law in violation of the freedom of association.

\section{Conclusion}

The African Court's decision places the Government of Tanzania at odds with the human rights principles of both the Organization of African Unity and the United Nations. The Court's skepticism about the Tanzanian Government's intentions and its Constitutional Review Commission process have proved prescient. Tanzania's Constitutional Review Commission produced two draft constitutions; the first, in spring 2013 and the second in fall 2014. Both draft versions provided for individual candidacies. However, the constitutional review process has now dragged on for another six years without any outcome. Although the Tanzanian Government had originally scheduled a popular referendum on the 2014 draft constitution for April 2015, it postponed the referendum until after the fall 2015 general election, citing difficulties in completing an up-dated registry of voters. In June 2016, the country's newly elected President, John Magufuli, announced that his government would carry the constitutional review process forward. It has yet to do so. The Constitutional Review Commission process is dormant as are the two draft constitutions. As of winter 2020, More than five years after the African Court's landmark decision, Tanzania's 1977 Constitution with its contradictory set of restrictive qualifications for parties, limitations on speech, and ban on unaffiliated candidacies remains in place.

The prospect of a new constitution that incorporates individual candidacies seems bleak. The governing party has consistently made its opposition to a new constitution clear. Its public position is that the present constitution serves Tanzania well. The government also seems determined to prevent further court cases. The possibility that Tanzania's National Assembly - about 80 percent of whose members represent the CCM - might take up the Court's challenge and change the constitution accordingly seems small. In February 2017, the Minister of Constitutional and Legal Affairs threated to withdraw registration from the Tanganyika Law Society because it had engaged in "activities of political activism [26]." Although his announcement did not specify the TLS role in supporting Mtikila at the African Court, his meaning was clear. A withdrawal of registration would have a chilling effect, creating reluctance on the part of Tanzanian attorneys who might wish to take up further constitutional lawsuits against the government. Most recently, the Government of Tanzania has threatened to withdraw from the African Court unless the court revises the protocol that permits individuals and NGOs to bring cases before it.

There is little likelihood of additional DP litigation. Reverend Christopher Mtikila died in an automobile accident in early October 2015, during the final weeks of the national election campaign. His death occurred as he was campaigning for his party in the northwest area of Tanzania, near the Rwanda border. During his final days, Mtikila had begun to vocalize another divisive ethnic viewpoint. His last speeches asserted the existence of an ethnic conspiracy consisting of members of the Tutsi - Hima communities, orchestrated by the Presidents of Rwanda and Uganda, to impose Tutsi domination over the Bantu peoples of eastern and central Africa. Leaders of Mtikila's party are suspicious of the circumstances of the fatal accident and several have called upon the government to investigate his death as a political assassination.

Sympathy for Reverend Mtikila and his libertarian views should not obscure the challenging political reality confronting the Tanzanian Government; namely, the seemingly global rise of populist political movements that thrive on racial, religious, and immigrant phobias. Against this background, Tanzania today confronts a dilemma common to many countries; namely, whether ethnic peace requires a legal framework that imposes constraints on political speech. Critics of Tanzania's unwillingness to change the constitution accuse the CCM of supporting the present arrangement because if affords significant electoral advantages. Supporters of the multi-cultural framework, however, insist that the wisdom behind the ban on individual candidates remains valid. Many Tanzanians agree with the government's view that permission for unaffiliated candidacies would only provoke a race to the bottom in the country's electoral process. They fear an environment in which individual candidates appealing to ethnic or religious constituencies could stand for office in opposition to registered party candidates whom the electoral law prevents from doing so. Some are convinced that if the government removes these restrictions, other aspiring political figures are ready to take Mtikila's place on the political stage. In such contests, the party-nominated candidate would inevitably come under great pressure to compete by appealing to ethnic identity.

This would inject an explosive element into the political arena. The most commonly cited metaphor for a legitimate restriction on speech has to do with the impermissibility of shouting "fire" in a crowded theater. Many Tanzanians consider ethnic and racial speech an exact equivalent.

\section{References}

[1] For an outstanding example, Richard W. Abel, Speaking Respect, Respecting Speech. Chicago: University of Chicago, 1998. 
[2] Suzanne B. Goldberg, "Free Expression on Campus: Mitigating the Costs of Contentious Speakers," in Harvard Journal of Law and Public Policy, Vol. 41, No 1, Winter 2018, pp. 171-172.

[3] Jacob Mchangama, "Europe's Freedom of Speech Fail, “Foreign Policy (FP), July 7, 2016.

[4] This court was created by Article 1 of the Protocol to the African Charter on Human and Peoples' Rights on the Establishment of an African Court on Human and People's Rights, which was adopted by the Organization of African Unity in 1998. The Protocol creating the Court came into effect in January, 2004. As of 2017, eight African countries had agreed to accept the jurisdiction of the Court. Tanzania was among these.

[5] Yaniv Roznai, Unconstitutional Constitutional Amendments: The Limits of Amendment Powers. Oxford, 2017.

[6] The United Republic of Tanzania, The Interim Constitution of Tanzania, 1965.

[7] The United Republic of Tanzania, The Constitution of the United Republic of Tanzania of 1977, Article 20 (2) (a)

[8] Grace Creek Media, Heaven on Earth: The Rise and Fall of Socialism: Rev. Christopher Mtikila Interview (2013).

[9] Richa Nagar. (1996). The South Asian Diaspora in Tanzania: A History Retold. Comparative Studies of South Asia, Africa and the Middle East, 16, 2, $62-80$.

[10] James R. Brennan, "Blood Enemies: Exploitation and Urban Citizenship in the Nationalist Political Thought of Tanzania, Journal of African History, Vol. 47, No. 3 (2006). See esp. pp. $404 \mathrm{ff}$.

[11] Ronald Aminzade, Race, Nation, and Citizenship in PostColonial Africa: The Case of Tanzania. New York, Cambridge University Press, 2013, p. 329.

[12] Paul J Kaiser. "Structural Adjustment and the Fragile Nation: the Demise of Social Unity in Tanzania." The Journal of Modern African Studies, vol. 34, no. 02, June 1996, p 233.

[13] The Political Parties Act [CAP 258 R. E. 2002].

[14] Constitutional Amendment Act No. 4 of 1992 appears as Article 3 (1) of the amended 1977 constitution.

[15] Rev. Christopher Mtikila v. the Attorney General, Civil Case No. 5 of 1993 in the High Court of Tanzania.
[16] The United Republic of Tanzania, An Act to provide the procedure for enforcement of constitutional basic rights and dutires and for related matters. No. 33 of 1994.

[17] The Eleventh Constitutional Amendment Act No. 34 of 1994 appears as Article 21 (1) of the present Tanzania Constitution.

[18] In The High Court of Tanzania (Dar es Salaam Main Registry), Misc. Civil Cause No 10 of 2005, Christopher Mtikila (Petitioner) versus The Attorney General (Respondent)

[19] The Court of Appeal of Tanzania at Dar es Salaam, Civil Appeal No. 45 of 2009, Between the Honourable Attorney General, Appellant and Christopher Mtikila, Respondent, "Judgment of the Court."

[20] Amnesty International Annual Report 2016/17,” pp. 357.

[21] Barnabas Samatta, "Judicial Protection of Democratic Values: The Judgmentof the Court of Appeal on Independent Candidates," as reprinted in Shivji, Issa G., and Hamudi Majamba. Rule of Law v. Rulers of Law: Justice Barnabas Albert Samattas Road to Justice. Dar es Salaam: Mkuki na Nyota, 2011, p. 239.

[22] African Charter on Human and People's Rights, Article 13, Section 1.

[23] United Nations, International Covenant on Civil and Political Rights, Section 2.

[24] Oliver Windridge, "A Watershed Moment for African Human Rights: Mtikila \& Others v Tanzania at the African Court on Human and Peoples Rights." African Human Rights Law Journal, vol. 15, no. 2, 2015, pp. 299-328.

[25] African Court on Human and People's Rights, "In the Consolidated Matter of 1. Tanganyika Law Society [and] 2. Legal and Human Rights Centre v. The United Republic of Tanzania," para 82.3.

[26] UN Human Rights Committee (HRC), CCPR General Comment No. 25: Article 25 (Participation in Public Affairs and the Right to Vote), The Right to Participate in Public Affairs, Voting Rights and the Right of Equal Access to Public Service, 12 July 1996, Paragraph 17.

[27] Zephania Ubwani, "EA Law Society: Minister Wrong to Threaten TLS," The Citizen, TZ, February 23, 2017. 